\title{
Evaluation of adsortive potential of coconut mesocarp in the removal of reactive red dye 195 in aqueous effluents
}

\author{
Avaliação do potencial adsortivo do \\ mesocarpo de coco na remoção de \\ corante vermelho reativo $195 \mathrm{em}$ \\ efluentes aquosos
}

Antonio do Nascimento Dantas Filho ${ }^{1}$, Edna Maria Mendes Aroucha ${ }^{1}$, Ricardo Henrique de Lima Leite ${ }^{1}$, Francisco Klebson Gomes dos Santos ${ }^{1}$

\footnotetext{
${ }^{1}$ Programa de Pós-graduação em Ciência e Engenharia de Materiais - PPGCEM/UFERSA, CEP: 59625-900, Mossoró, RN, Brasil.

e-mail:klebson@ufersa.edu.br, an.df@hotmail.com, aroucha@ufersa.edu.br, ricardoleite@ufersa.edu.br
}

\begin{abstract}
The textile industry produces dye-rich effluents that when released in hydric bodies hamper the penetration of sunlight, impairing photosynthetic processes. Besides that, dyes have been indicated as potentially toxic substances. In general, the processes of removing of these contaminants have been much studied, with the technique of adsorption standing out for its high efficiency, in addition to operational advantages and the possibility of reuse agricultural waste as adsorbents, benefiting the environment and reducing costs. The present work had as objective to study the performance of coconut mesocarp utilized as adsorbent in the bleaching process of synthetic effluent containing 25 g. $\mathrm{L}^{-1}$ of reactive red 195 dye. The adsorbent were characterized by granulometry, thermogravimetric analysis and zero point charge. Kinetic and balance study was realized, applying kinetic models and adsorption isotherms. The adsorbent exhibited removal efficiency of $89.92 \%$ in $120 \mathrm{~min}$. The maximum adsorption capacity was $24.04 \mathrm{~g} . \mathrm{g}^{-1}$ at $30^{\circ} \mathrm{C}$. The kinetic study showed that the data was better adjusted by an Elovich equation, indicating slow chemisorption. The thermodynamic study exhibited that the adsorption process is exothermic and spontaneous for all the temperatures evaluated.
\end{abstract}

Keywords: Adsorption; Coconut mesocarp; Dye.

\section{RESUMO}

A indústria têxtil produz efluentes ricos em corantes que, quando liberados em corpos hídricos, dificultam a penetração da luz solar, prejudicando os processos fotossintéticos. Além disso, os corantes foram indicados como substâncias potencialmente tóxicas. Em geral, os processos de remoção desses contaminantes têm sido muito estudados, destacando-se a técnica de adsorção por sua alta eficiência, além de vantagens operacionais e a possibilidade de reutilização de resíduos agrícolas como adsorventes, beneficiando o meio ambiente e reduzindo custos. O presente trabalho teve como objetivo estudar o desempenho do mesocarpo de coco utilizado como adsorvente no processo de branqueamento de efluente sintético contendo $25 \mathrm{~g} . \mathrm{L}^{-1}$ de corante vermelho reativo 195. Os adsorventes foram caracterizados por granulometria, análise termogravimétrica e potencial de carga zero. Realizou-se estudo cinético e de equilíbrio, aplicando-se modelos cinéticos e isotermas de adsorção. O adsorvente exibiu eficiência de remoção de 89,92 \% em 120 min. A capacidade máxima de adsorção foi de $24,04 \mathrm{~g} \cdot \mathrm{g}^{-1}$ a $30{ }^{\circ} \mathrm{C}$. O estudo cinético mostrou que os dados foram melhor ajustados pelo modelo de Elovich, indicando quimissorção lenta. O estudo termodinâmico mostrou que o processo de adsorção é exotérmico e espontâneo para todas as temperaturas avaliadas.

Palavras-chave: Adsorção; Mesocarpo de coco; corante. 


\section{INTRODUCTION}

The textile industry in Brazil plays an important role in the economy both in the creation of employment and in the value of industrial production. Data released by the Sectorial Report of the Brazilian Textile Industry (2016) show that in 2015 the sector was responsible for employing 1.5 million jobs or $16.9 \%$ of total employment in the industrial sector, while in monetary terms it represented the sale of US\$ 53.4 billion. This corresponds to $5.6 \%$ of the manufacturing industry (excluding construction and mining), which represented $2.5 \%$ of GDP, (The Genuine Progress Indicator: A Measure of Net Economic Welfare), in 2015 [1].

The industrial sector is responsible for several environmental problems, since it presents high amount of organic load and color in its effluent, altering the quality of the receiving bodies. The dyes present in the tailings of these industries cause, besides a visual pollution, inhibition to the aquatic life and the photosynthetic activity, as they interfere in the penetration of sunlight and interfere in the biological processes of the water body, and as aggravating it has its degree of toxicity, acute and/or chronic effects on organisms, depending on the concentration and time of exposure [2].

The selection of the water treatment process is a complex task that takes into account many factors which include space available for the construction of treatment facilities, process equipment reliability, waste disposal restrictions, desired quality of finished water and costs of capital and operation. Treatment of wastewater to make it suitable for later use may require physical, chemical and biological processes. Several technologies are available with varying degrees of success to control water pollution. Some of them are coagulation, flotation, filtration, ion exchange, aerobic and anaerobic treatment, advanced oxidation processes, solvent extraction, electrolysis, microbial reduction and adsorption. However, most of them require a substantial financial input [3] .

Adsorption is one of the most efficient methods used for the removal of various contaminants in wastewater. It was successfully used in discoloration of different classes of dyes in textile effluents. However, one of the main disadvantages of this process is the high cost of obtaining suitable adsorbents. To make it an economically viable technique, the development of low-cost adsorbents is necessary, so there is a growing interest in the development and application of agricultural waste for this purpose. Among several agricultural residues studied as adsorbents for treatment and purification of wastewater, coconut mesocarp have been a good alternative for dye removal, presenting low cost and high efficiency [4].

Considering the importance of the textile industry in the national market and the need to develop adequate treatment of its effluents, the present work aims to evaluate the technique of purification of water contaminated with reactive red dye 195 by adsorption through the use of bagasse coconuts.

\section{MATERIALS AND METHODS}

\subsection{Adsorbent material preparation}

The coconut mesocarp, a residue obtained from coconut (Cocos nucifera) was obtained in local commerce from the city of Mossoró-RN, Brazil. Its preparation consisted of the removal of the green bark and the rigid part. The adsorbent was crushed in a knife mill, washed to remove any contaminants, oven drying with air renovation, grinding and, finally, sorted in sieves. The mesocarp was cut into cubic pieces and then ground into a knife mill, then immersed in distilled water for 3 hours to diffuse the aqueous phase of the sucrose and other water-soluble components, avoiding their future decomposition. After this step the material was conditioned in a tissue strainer and washed with distilled water until it had no absorbance in the visible region. Finally, the adsorbent was manually pressed to remove excess water. In order to remove residual moisture from the adsorbents, this material was transferred to Tecnal model TE-394/1 air circulation drying oven at $60{ }^{\circ} \mathrm{C}$ for 24 hours. After drying the adsorbent material was ground in SL-31 knife mill, brand Solab. In order to standardize the biomass, the material was classified according to its granulometry. A series of eight Tyler sieves with $8,9,14,18,35,60,100$ and 200 mesh were used.

\subsection{Thermogravimetric analysis}

Thermogravimetric analysis performed on coconut mesocarp with and without alkaline treatment was performed to investigate the degree of thermal stability of each sample. A thermogravimetric analyzer and simultaneous calorimeter, model TG209F1 Libra and manufacturer NETZSCH were used for the analysis. All tests were performed according to the following parameters: alumina crucible; nitrogen purge gas; 40 $\mathrm{mL} \cdot \mathrm{min}^{-1}$ purge gas flow rate; heating rate of $10^{\circ} \mathrm{C}$. $\mathrm{min}^{-1}$. Final temperature of $1000^{\circ} \mathrm{C}$ and sample mass of $6 \mathrm{mg}$. 


\subsection{Zero charge point (ZCP)}

For the determination of the zero charge point, the methodology proposed by PERILLI et al.,[5] and PRAHAS et al. [6] denominated the drift method, which consists in the addition of the adsorbent material in a saline solution with pre-determined $\mathrm{pH}$ ranges. When the saline solution and the adsorbent enter into equilibrium, the $\mathrm{pH}$ variation will indicate the charge of the material. $50 \mathrm{~mL}$ of $0.01 \mathrm{~mol} . \mathrm{L}^{-1}$ aqueous $\mathrm{NaCl}$ solution were prepared under different initial $\mathrm{pH}$ values $(0,1,2,3,4,5,6,7,8,9,10,11$ and 12). Then, $0.15 \mathrm{~g}$ of the coconut mesocarp was added to each sample and they were shaken for 24 hours under constant stirring at 200 $\mathrm{rpm}$ in the SLAB $2200 \mathrm{SLAB}-222$ at the temperature of $30^{\circ} \mathrm{C}$. After the stipulated time, the final $\mathrm{pH}$ value of the solutions was checked and the final $\mathrm{pH}$ plot plotted as a function of the initial $\mathrm{pH}$.

\subsection{Red reactive dye removal study}

From a reactive red solution 195 with a concentration of $25 \mathrm{mg} . \mathrm{L}^{-1}$, a point-to-point analysis scan was performed in the visible region to obtain the maximum absorption wavelength of the dye. It was found that it was $520 \mathrm{~nm}$ wavelength, which was used to perform the calibration curve. Solutions were produced from 25 to $400 \mathrm{mg} \cdot \mathrm{L}^{-1}$. A spectrophotometer, model EVO600PC, THERMO was used.

\subsection{Obtaining the adsorption kinetics for the adsorbent}

To construct the kinetics, $0.4 \mathrm{~g}$ of adsorbent was added to $100 \mathrm{~mL}$ of reactive red dye solution 195 with initial concentration of $25 \mathrm{mg} . \mathrm{L}^{-1}$ in $250 \mathrm{~mL}$ erlenmeyers. The $\mathrm{pH}$ of these samples was adjusted to 1.0 with 1.0 mol. $\mathrm{L}^{-1}$ hydrochloric acid and these were shaken at $200 \mathrm{rpm}$ in shaker (Model SL 222, brand Solab). At regular intervals, aliquots were withdrawn for analysis until the equilibrium was reached and the concentration of the remaining solution was determined by the spectrophotometric techniques mentioned above. The experimental results were adjusted to the models of pseudo-first order, pseudo-second order, intraparticle diffusion, Elovich and Avrami.

\subsection{Study of the $\mathrm{pH}$ influence}

An important factor in the adsorption experiments is the effect of the $\mathrm{pH}$ of the medium on the adsorption capacity of the ion in the adsorbent. The $\mathrm{pH}$ of the medium interferes with this mechanism, affecting the adsorption capacity of the adsorbent due to competition for active sites and changes in their surface loads [11]. To evaluate the influence of the $\mathrm{pH}, 100 \mathrm{~mL}$ of solution, $25 \mathrm{mg} \cdot \mathrm{L}^{-1}$ reactive red dye, in $250 \mathrm{~mL}$ erlenmeyers under constant stirring at $200 \mathrm{rpm}$ shaker (Model SL 222, brand Solab), with pH corresponding to 0, 1, 2, 3, 4, $5,6,8,10,11$ and 12 were used. The $\mathrm{pH}$ values were adjusted using $1.0 \mathrm{~mol} \cdot \mathrm{L}^{-1} \mathrm{HCl}$ and $\mathrm{NaOH}$ and were measured with TECNAL pH meter, model TEC-3MP. At regular intervals, aliquots were taken for analysis of the concentration of the dye until it did not change.

\subsection{Isotherms of adsorption}

In order to evaluate the adsorbent efficiency, adsorption isotherms were determined. Thus, with equilibrium time defined in the kinetic test, adsorption isotherms were constructed which are tests where the amount of solute in the liquid phase $\left(\mathrm{C}_{\mathrm{e}}\right)$ is correlated with the amount of solute adsorbed by the adsorbent $\left(\mathrm{q}_{\mathrm{e}}\right)$ under different operating conditions. The isotherms were determined by adding $0.4 \mathrm{~g}$ of the adsorbent in $100 \mathrm{~mL}$ of the reactive red dye solution 195 at the concentrations of $25,50,75,100,125,150$ and $175 \mathrm{mg} . \mathrm{L}^{-1}$; the blends were transferred to $250 \mathrm{~mL}$ erlenmeyers and kept under constant stirring at $200 \mathrm{rpm}$ shaker (Model SL 222, brand Solab). These solutions were adjusted with $1.0 \mathrm{~mol} . \mathrm{L}^{-1}$ hydrochloric acid solution for the best performance $\mathrm{pH}$ found in the $\mathrm{pH}$ influence test. At equilibrium, aliquots from each vial were withdrawn and quantified by reading the absorbance in a UV-VIS spectrophotometer (model EVO600PC-THERMO). The experimental data of the variation of $\mathrm{q}_{\mathrm{e}}\left(\mathrm{mg} \cdot \mathrm{g}^{-1}\right)$ as a function of $\mathrm{C}_{\mathrm{e}}\left(\mathrm{mg} \cdot \mathrm{L}^{-1}\right)$ were adjusted by the Langmuir and Freundlich models.

\subsection{Thermodynamic Study}

By determining the thermodynamic parameters it is possible to highlight some factors involved in the adsorption process, such as the spontaneity of the adsorption reaction, whether it occurs endothermically or exothermically and whether the reaction is viable with temperature variation. 


\section{RESULTS}

\subsection{Thermogravimetric analysis}

The thermal stability of the adsorbent fibers was evaluated by thermogravimetric analysis, shown in Figure 1.

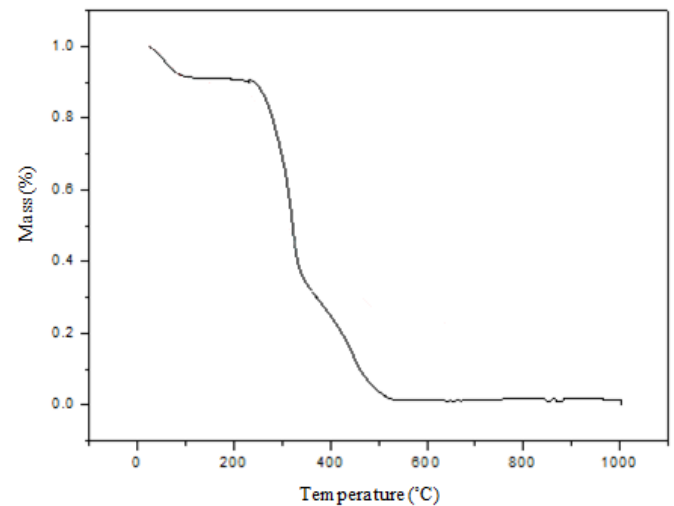

Figure 1: Thermogravimetric analysis (TGA) of coconut mesocarp.

The first loss of mass, between $100{ }^{\circ} \mathrm{C}$ and $150{ }^{\circ} \mathrm{C}$, is attributed to the simultaneous loss of volatile compounds and water vaporization [7]. Hemicellulose, due to its amorphous nature, decomposes between temperatures of $200-260{ }^{\circ} \mathrm{C}$, while cellulose is thermally degraded between $240-360{ }^{\circ} \mathrm{C}$ and lignin, between 280 and $360{ }^{\circ} \mathrm{C}$. It is also possible to observe the loss of mass at a temperature of $270{ }^{\circ} \mathrm{C}$, which is related to the degradation of the hemicellulose, and also another increase in the reduction of the mass value around 330 ${ }^{\circ} \mathrm{C}$, mainly due to the thermal degradation of the cellulose. Two peaks in the range of 350 to $550{ }^{\circ} \mathrm{C}$ are observed, which are probably due to the thermal degradation of cellulose and lignin. It is not possible to separate the degradation processes of the fiber components (lignin, cellulose and hemicellulose) due to the complexity of the reactions and the overlap of degradation peaks [8].

\subsection{Zero charge potential (ZCP)}

Figure 2 shows the relationship between the initial and final $\mathrm{pH}$ of the solutions. From this it is possible to determine the zero load point by making an arithmetic mean of the points at which the final $\mathrm{pHs}$ remain constant.

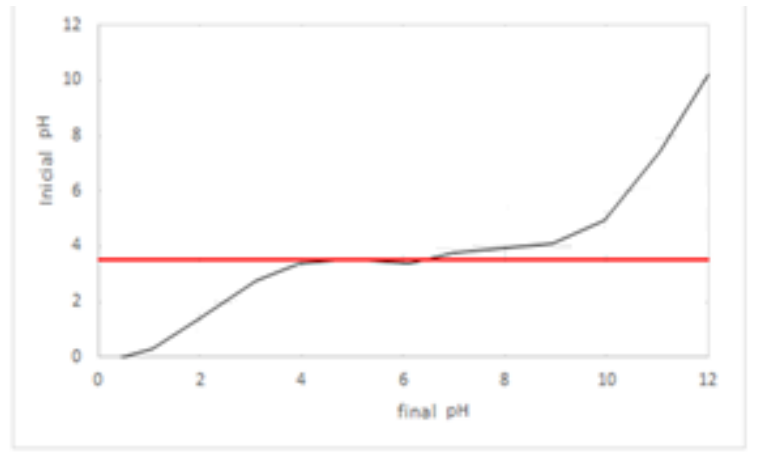

Figure 2: Zero charche Potential (ZCP) of coconut mesocarp.

According to results showed in Figure 2 the ZCP was 3.5. When a solid material contacts a liquid solution having a $\mathrm{pH}$ below $\mathrm{ZCP}$, the surface is positively charged and a large number of anions are adsorbed to balance the positive charges. Thus, the adsorbents are more effective for the removal, for example, of anionic materials. In aqueous solutions with a higher $\mathrm{pH}$ than $\mathrm{ZCP}$, the surface is negatively charged and adsorb, preferably, cations. In this case, the adsorbents are more effective for the removal of cationic materials [9]. FONTOURA et al. [10], in their research with algae biomass to remove acid blue dye 161, observed that the material used presented a zero load potential equal to 4.2, obtaining good removal in the region of $\mathrm{pH}$ lower than this value. 


\section{$3.3 \mathrm{pH}$ influence on adsorption}

Figure 3 shows the adsorption capacity and percentages of adsorption of coconut mesocarp as a function of $\mathrm{pH}$.

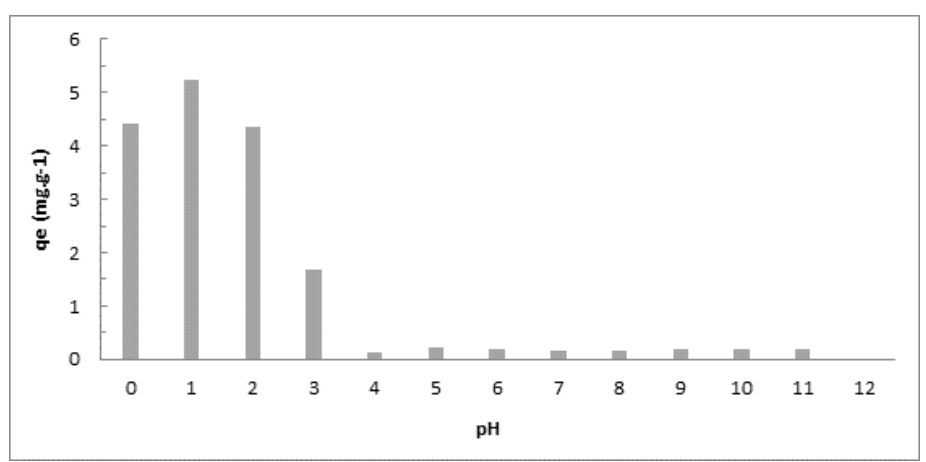

Figure 3: Evaluation of the behavior of the coconut mesocarp removal capacity as a function of $\mathrm{pH}$.

Analyzing Figure 3 it can be observed that the coconut mecoarpo has a greater capacity of red reactive dye removal at acidic $\mathrm{pH}$, achieving a removal of $85 \%$. This behavior can be explained by the modification of the surface charges of this material, which tend to be positive at low $\mathrm{pH}$ values and become negative with increasing $\mathrm{pH}$. The zero charge point of the coconut mesocarp was 3.5, confirming a negative charge of dye.

\subsection{Kinetic study}

Table 1 shows the results of the kinetic models.

Table 1: Kinetic models applied to the coconut mesocarp.

\begin{tabular}{|c|c|c|c|}
\hline KINETIC MODEL & EQUATION & PARAMETERS MODELS & $\mathbf{R}^{2}$ \\
\hline Pseudo- $1^{\mathrm{a}}$ order & $q_{t}=q_{e}\left(1-e^{-k_{1} t}\right)$ & $\begin{array}{c}\mathrm{q}_{\mathrm{e}}=5.05 \\
\mathrm{k}_{1}=7.54 \times 10^{-2}\end{array}$ & 0.897 \\
\hline Pseudo-2 ${ }^{\mathrm{a}}$ order & $q_{t}=\frac{k_{2} q_{e}^{2} t}{1+q_{e} k_{2} t}$ & $\begin{array}{c}\mathrm{q}_{\mathrm{e}}=5.41 \\
\mathrm{k}_{2}=2.06 \times 10^{-3}\end{array}$ & 0.968 \\
\hline Intraparticle diffusion & $q_{t}=k_{i d} \sqrt{t}+C$ & $\begin{aligned} \mathrm{k}_{\mathrm{id}} & =0.423 \\
\mathrm{C} & =0.0\end{aligned}$ & 0.468 \\
\hline Elovich & $q_{t}=\frac{1}{\beta}(\ln \alpha \beta+\ln t)$ & $\begin{array}{l}\alpha=1.22 \\
\beta=3.014\end{array}$ & 0.997 \\
\hline Avrami & $q_{t}=q_{e}\left(1-e^{\left(-k_{A V} t\right)^{n}}\right)$ & $\begin{array}{c}\mathrm{q}_{\mathrm{e}}=5.032 \\
\mathrm{k}_{\mathrm{AV}}=1.954 \\
\mathrm{n}=0.039\end{array}$ & 0.895 \\
\hline
\end{tabular}

By evaluating the correlation coefficient $\left(\mathrm{R}^{2}\right)$ of the presented data it is clear to observe that the model to which the experimental data fit most was Elovich. According to AL-JABARI [12], this model is used for general application to chemisorption, covering a wide range of slow adsorption rates. The same equation is often valid for systems in which the surface of the adsorbent is heterogeneous. It can be verified the good fit of the model to the experimental data. 


\subsection{Isotherm of adsorption}

The data of isotherm of adsorption obtained are shown in Figures 4.

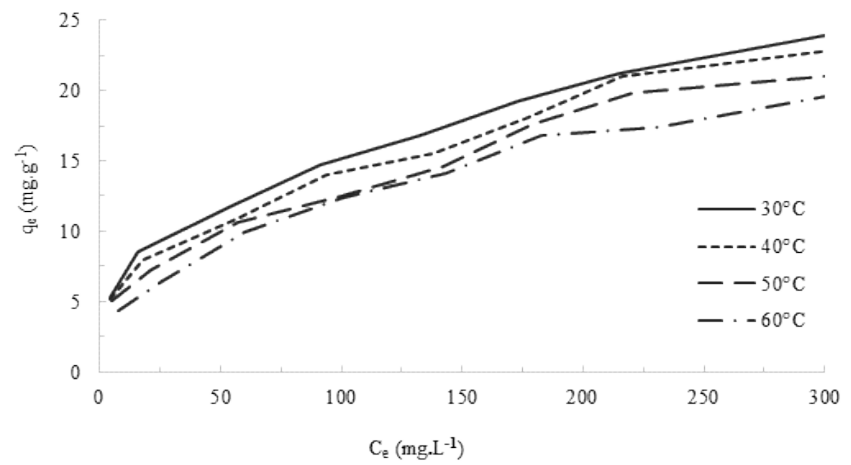

Figure 4: Isotherm of the experimental data of coconut mesocarp.

According to the classification of PETROVIC [13], from the profile of the graph obtained for the adsorption at the four temperatures evaluated, it can be inferred that it is the isotherm where the maximum adsorbed quantity becomes constant at a certain temperature, that is, evidence the formation of a monolayer. This type of isotherm is characteristic of microporous solids with relatively small external surface. The contaminant adsorb at the active sites of the external surface, which once occupied do not allow additional adsorption to occur, thus raising the concentration of adsorbate in the medium there will be a reduction of the availability of sites for adsorption allowing the saturation of the surface.

Isotherms in this profile indicate favorable adsorptions, characteristics of a chemical nature. From the results obtained from the isotherms it is possible to express the maximum amount that the adsorbent was able to remove in order to reach equilibrium.

Experimental data for adsorption show that as the temperature increases the amount of solute adsorbed per mass of adsorbent decreases, indicating that the adsorption process is exothermic. It is known that the coconut mesocarp does not suffer great variations in its capacity to adsorb when subjected to different temperatures.

With the obtained values of the adsorption isotherms it is possible to evaluate the nature of the interaction between adsorbent and adsorbate through isothermal models. The results were studied comparing the Langmuir and Freundlich models. The results are expressed in Table 2.

Table 2: Comparison of the results of the Langmuir and Freundlich isotherm models applied to the coconut mesocarp.

\begin{tabular}{|c|c|c|c|c|c|c|c|}
\hline \multirow{2}{*}{$\begin{array}{l}\text { TEMPERATURE } \\
\left({ }^{\circ} \mathbf{C}\right)\end{array}$} & \multicolumn{3}{|c|}{$\begin{array}{l}\text { LANGMUIR MODEL } \\
\text { PARAMETERS }\end{array}$} & \multicolumn{4}{|c|}{$\begin{array}{l}\text { FREUNDLICH MODEL } \\
\text { PARAMETERS }\end{array}$} \\
\hline & $\begin{array}{c}Q_{M A ́ x} \\
(m g / g)\end{array}$ & $\begin{array}{c}\mathrm{K} \mathrm{L} \\
(\mathrm{L} / \mathrm{mg})\end{array}$ & $\mathbf{R}^{2}$ & $K_{F}(m g / g)$ & $\mathbf{n}$ & $1 / n$ & $\mathbf{R}^{2}$ \\
\hline 30 & 26.05 & 00.018 & 0.898 & 2.786 & 2.669 & 0.375 & 0.994 \\
\hline 40 & 26.376 & 00.014 & 0.890 & 2.375 & 2.532 & 0.395 & 0.983 \\
\hline 50 & 25.210 & 00.013 & 0.896 & 2.130 & 2.490 & 0.401 & 0.978 \\
\hline 60 & 23.932 & 0.012 & 0.956 & 1.703 & 2.327 & 0.429 & 0.995 \\
\hline
\end{tabular}


Evaluating the linear regression coefficient $\left(\mathrm{R}^{2}\right)$ of the presented data, it is possible to see that the model to which the experimental data fit was the Freundlich model. According to SILLANPÄ̈̈ et al. [14], the adsorption of dyes on cellulosic fibers is typically associated with Freundlich isotherm. Sorption theory teaches that the interaction between dye molecules and cellulosic fibers is based on hydrogen bonds and van der Waals interactions. The constants $\mathrm{K}_{\mathrm{F}}$ and $1 / \mathrm{n}$ are Freundlich constants. The constant $\mathrm{K}_{\mathrm{F}}$ is an approximate measure of the adsorption capacity of the adsorbent. The higher value, the greater the adsorption capacity. Values of $\mathrm{n}$ in the range $1<\mathrm{n}<10$ indicate favorable adsorption, which was observed for all adsorbent materials. The constant $1 / \mathrm{n}$ has a value between 0 and 1 and is related to the heterogeneity of the surface. The closer to zero, the more heterogeneous the surface. Similar behavior was observed by CHANG et al. [15] studied the adsorption of crystal violet by rice hull modified with sodium hydroxide solution at temperatures of 20, 30 and $40{ }^{\circ} \mathrm{C}$. The increase in temperature resulted in a decrease in the parameters of the Freundlich model. The decrease in $\mathrm{K}_{\mathrm{F}}$ values at higher temperatures suggests that the adsorption process was favorable at lower temperatures. The $\mathrm{n}$ is an empirical parameter that varies with the degree of heterogeneity and is related to the distribution of adsorbed ions on the sorbent surface. In general, $n>1$ illustrates that the adsorbent is adsorbed favorably on an adsorbent and, the higher the value of $\mathrm{n}$, the stronger the adsorption intensity. In particular, it was observed that the value of $\mathrm{n}$ is significantly greater than unity at all temperatures studied. However, $n$ decreases with increasing temperature showing that the rate of adsorption decreases. In general, the information thus obtained specifies an exothermic nature of the existing process.

Table 3 shows some results for adsorption capacity of same adsorpents based on coconut mesocarp to remove dyes from aqueous solutions.

Table 3: Adsorption capacities of coconut-based biosorbents for the removal of various dyes from water.

\begin{tabular}{|c|c|c|c|}
\hline ADSORBENT & ADSORBATE & ADSORPTION CAPACITY & REFERENCE \\
\hline rice husk carbon & acid yellow 36 & $86.9 \mathrm{mg} \cdot \mathrm{g}^{-1}$ & Malik (2003) \\
\hline coconut treeflower carbon & eactive red dye & $81.9 \mathrm{mg} \cdot \mathrm{g}^{-1}$ & Senthilkumaar et al. 2006 \\
\hline coconut coir dust & methylene blu & $14.36 \mathrm{mg} \cdot \mathrm{g}^{-1}$ & Macedo et al. 2006 \\
\hline $\begin{array}{l}\text { hermally activated coco- } \\
\text { nutcoir activated carbon }\end{array}$ & methylene blu & $5.59-20.62 \mathrm{mg} \cdot \mathrm{g}^{-1}$ & Sharma and Uma 2009 \\
\hline hawthorn kernel & methylene blue & $49.5 \mathrm{mg} \cdot \mathrm{g}^{-1}$ & Akköz et al. (2019) \\
\hline coconut mesocarp & red dye 195 & $26.4 \mathrm{mg} \cdot \mathrm{g}^{-1}$ & This work \\
\hline
\end{tabular}

Analyzing Table 3, it can be seen that the maximum adsorption capacity of the red dye 195, in this work, was $26.4 \mathrm{mg} \cdot \mathrm{g}^{-1}$. It is worth mentioning that the coconut mesocarp adsorbent did not undergo any type of treatment, that is, it was used in natura. The adsorbent reached a removal of $89.9 \%$ in the conditions of $\mathrm{pH}$ equal to 1.0 , temperature of $30^{\circ} \mathrm{C}$ and constant agitation of $200 \mathrm{rpm}$.

\subsection{Thermodynamic study}

Experimental data for thermodynamic study can be evaluated by analyzing Table 4. 
Table 4: Thermodynamic study for the coconut mesocarp in the removal of reactive red dye 195.

\begin{tabular}{|c|c|c|c|}
\hline TEMPERATURE $\left({ }^{\circ} \mathrm{C}\right)$ & $\Delta \mathbf{G}\left(\mathrm{kJ} \cdot \mathrm{mol}^{-1}\right)$ & $\Delta \mathrm{H}\left(\mathrm{kJ} . \mathrm{mol}^{-1}\right)$ & $\Delta S\left(\right.$ kj.mol. $\left.{ }^{-1} K^{-1}\right)$ \\
\hline 30 & -2.58 & \multirow{7}{*}{-13.36} & \multirow{7}{*}{-0.035} \\
\hline 40 & -2.25 & & \\
\hline 50 & -2.03 & & \\
\hline 60 & -1.47 & & \\
\hline 40 & 0.51 & & \\
\hline 50 & 0.94 & & \\
\hline 60 & 1.32 & & \\
\hline
\end{tabular}

As all the values found for the Gibbs free energy in the adsorption process using the coconut mesocarp were negative, it is concluded that the adsorption process is spontaneous and thermodynamically feasible at all temperatures tested. The process was shown, as indicated above, to be exothermic due to the negative values of the enthalpy change. An explanation for this fact lies in the extensive formation of interactions between the surface of the adsorbent and adsorbate particles, a naturally exoenergetic process, as it occurs with a decrease in the potential energy of each of the parts involved in the formed bond. The negative value of the adsorption entropy variation indicates an increase in the degree of organization of the system, associated to the adsorbate particles' accommodation in more ordered layers on the surface of the adsorbent. It further indicates that there is no dissociation or increase in the mobility of the particles on the surface of the adsorbent. The results obtained in the present study were similar to those obtained by VELAZQUEZ-JIMENEZ et al. [9], where the extraction of aqueous solutions of dyestuffs (remazol 160 blue, ruby S2G, red remazol 5, remazol 5 violet and indantrone olive green) were evaluated by the babassu coconut (Attalea speciosa) mesocarp temperatures of $25,35,45$ and $55^{\circ} \mathrm{C}$. The exothermic enthalpy for the dye adsorption process presented values in the range of -26.1 to $-15.8 \mathrm{~kJ} \cdot \mathrm{mol}^{-1}$, indicating a formation of chemical bonds between the molecules and the adsorbent surface. The Gibbs free standard energy presented a negative value, indicating spontaneity of the reaction; the enthalpy values were also negative, reflecting an ordering arrangement of the water molecules initially attached to the biopolymer or the dye as the chemisorption progresses.

\section{CONCLUSION}

The coconut mesocarp was shown to be a viable alternative for the adsorption of the reactive red dye 195 . The adsorbent reached a removal of $89.92 \%$ in the conditions of $\mathrm{pH}$ equal to 1.0 , temperature of $30{ }^{\circ} \mathrm{C}$ and constant agitation of $200 \mathrm{rpm}$. The kinetic study allowed analyzing the behavior of the adsorption over time, in addition to studying the models that best fit the experimental data. The coconut mesocarp was better fitted in Elovich model, leading to the conclusion that it would be a slow chemisorption relation. The study of the adsorption isotherms allows concluding that the process is favorable reactions. The model that best fit was Freundlich's. Through the thermodynamic study it was possible to conclude that during adsorption it is an exothermic process, however spontaneous at all temperatures for the coconut mesocap. This work demonstrated that the coconut mesocarp has potential for the removal of reactive red dye 195, being a viable alternative for the treatment of effluents contaminated with the dye, without any treatment.

\section{ACKNOWLEDGMENTS}

The authors thank PPGCEM/UFERSA.

\section{BIBLIOGRAPHY}

[1] LUCATO, W. C., COSTA, E. M., NETO, G. C. O., "The environmental performance of smes in the brazilian textile industry and the relationship with their financial performance", Journal of Environmental Management, v. 203, n. 1, pp. 550-556, 2017.

[2] VASQUES, A. R., SOUZA, S. A. G., WEISSENBERG, L., et al., "Adsorção dos corantes RO16, RR2 E RR141 utilizando lodo residual da indústria textile”, Eng. Sanit. Ambient. v. 16, n. 3, pp. 245-252, 2011. 
[3] BHATNAGAR, A., SILLANPÄÄ, M., "Utilization of agro-industrial and municipal waste materials as potential adsorbents for water treatment-a review", Chemical Engineering Journal, v. 157, n. 2, pp. 277$296,2010$.

[4] UMH, H. N., KIM, Y., "Journal of Industrial and Engineering Chemistry Sensitivity of nanoparticles stability at the point of zero charge ( PZC )", Journal of Industrial and Engineering Chemistry, v. 20, n. 5, pp. 3175-3178, 2014

[5] PERILLI, T. A. G., SICUPIRA, D. C., MANSUR, M. B., et al., “Avaliação da capacidade adsortiva de carvão ativado para a remoção de manganês”, Rev. Holos, v. 3, pp. 264-271, 2014.

[6] PRAHAS, D., KARTIKA, Y., INDRASWATI, N et al., "Activated carbon from jackfruit peel waste by $\mathrm{H}_{3} \mathrm{PO}_{4}$ chemical activation: Pore structure and surface chemistry characterization", Chemical Engineering Journal, v. 140, pp. 32-42, 2008.

[7] AL-JABARI, M., "Kinetic models for adsorption on mineral particles comparison between Langmuir kinetics and mass transfer”, Environmental Technology and Innovation, v. 6, pp. 27-37, 2016.

[8] VACCHI, F. I., OHE, P. C. V. D., ALBUQUERQUE, A. F. DE., et al., "Occurrence and risk assessment of an azo dye - the case of disperse red 1", chemosphere, v. 156, pp. 95-100, 2016.

[9] VELAZQUEZ-JIMENEZ, L. H., PAVLICK, A., RANGEL-MENDEZ, J. R., "Chemical characterization of raw and treated agave bagasse and its potential as adsorbent of metal cations from water", Industrial Crops and Products, v. 43, pp. 200-206, 2013.

[10] FOMINA, M., GADD, G. M., "Biosorption: current perspectives on concept, definition and application", Bioresource Technology, v. 160, pp. 3-14, 2014.

[11] KHOSRAVI, R., AZIZI, A., GHAEDRAHMATI, R., et al., "Adsorption of gold from cyanide leaching solution onto activated carbon originating from coconut shell-Optimization, kinetics and equilibrium studies", Journal of Industrial and Engineering Chemistry, v. 54, pp. 464-471, 2017.

[12] L-JABARI, M., "Kinetic models for adsorption on mineral particles comparison between Langmuir kinetics and mass transfer", Environmental Technology and Innovation, v. 6, pp. 27-37, 2016.

[13] PETROVIC, M., SOSTARIC, T., STANOJOVIC, M., et al., "Mechanism of adsorption of $\mathrm{Cu}^{2+}$ and $\mathrm{Zn}^{2}$ + on the corn silk ( Zea mays L .)", Ecologic Enginiring, v. 99, pp. 83-90, 2017.

[14] SILLANPÄ̈̈, M., NCIBI, M. C., MATILAINEN, A., et al., "Removal of natural organic matter in drinking water treatment by coagulation: a comprehensive review”, Chemosphere, v. 190, pp. 54-71, 2018.

[15] CHANG, Y., LAI, J., LEE, D., "Bioresource Technology Thermodynamic parameters for adsorption equilibrium of heavy metals and dyes from wastewaters : Research updated", Bioresource Technology, v. 222, pp. 513-516, 2016.

\section{ORCID}

Antonio do Nascimento Dantas Filho Edna Maria Mendes Aroucha Ricardo Henrique de Lima Leite Francisco Klebson Gomes dos Santos http://orcid.org/0000-0003-4999-6251

http://orcid.org/0000-0003-1530-4114

http://orcid.org/0000-0003-0802-6742

http://orcid.org/0000-0003-4542-6382 